\title{
Kekerasan Dalam Rumah Tangga (KDRT) Terhadap Perempuan: Perspektif Pekerjaan Sosial
}

\author{
Agung Budi Santoso \\ email: agungbudi9278@gmail.com
}

\begin{abstract}
:
National Commission on violence against women (2015) noted that violence against women showed a widespread pattern. The 2016 annual press release (Catahu) released that there were 321,752 of violence cases. The largest type of violence against women was violence in the personal sector. Violence in the form of rape was $72 \%$ (2,399 of cases), violence in the form of obscenity was $18 \%$ (601 of cases), and sexual abuse was 5\% (166 of cases). The majority of personal violence victims (domestic / household) were women. The forms of domestic violence included physical violence, psychological violence, sexual violence and neglect of the household; while the main factor was the lack of communication and disharmony among family members. The impact in the short term was usually like a physical injury, disability, pregnancy, loss of work, and so forth; while the long-term effects were psychological disorders (psychiatric), loss of confidence, fend for oneself, trauma and appearance of fear to depression. The handling of domestic violence is one of the focuses of social workers to play a role in helping / assisting the recovery of victims. The social worker should be able to convince the victims to dare to express their problems, to give a sense of security, and comfort. Social workers in helping victims of domestic violence should have knowledge and alignment to the victims that the slightest violence is a form of crime against humanity. Victims of domestic violence must immediately obtain the protection, security assurance and social assistance. The efforts which can be done by social workers are counseling and family counseling. Those are done as a form of therapy so that victims do not feel the prolonged trauma and they can think calmly.
\end{abstract}

Keywords: Domestic Violence, Women, Social Work

\section{A. Pendahuluan}

Kekerasan terutama kekerasan dalam rumah tangga merupakan pelanggaran hak asasi manusia dan kejahatan terhadap martabat kemanusiaan serta merupakan bentuk diskriminasi. Kekerasan dalam bentuk apapun dan dilakukan dengan alasan apapun merupakan bentuk kejahatan yang tidak dapat dibenarkan. Oleh karena itu, sekecil apapun kekerasan yang dilakukan dapat dilaporkan sebagai tindak pidana yang 
dapat di proses hukum. Kekerasan dalam rumah tangga (KDRT) adalah setiap perbuatan terhadap seseorang terutama perempuan, yang berakibat timbulnya kesengsaraan atau penderitaan secara fisik, seksual, psikologis, dan/atau penelantaran rumah tangga termasuk ancaman untuk melakukan perbuatan, pemaksaan, atau perampasan kemerdekaan secara melawan hukum dalam lingkup rumah tangga. ${ }^{1}$

Istilah $\mathrm{KDRT}^{2}$ sebagaimana ditentukan pada Pasal 1 angka 1 Undang-Undang Nomor 23 Tahun 2004 tentang Penghapusan Kekerasan Dalam Rumah Tangga (UU PKDRT) tersebut seringkali disebut dengan kekerasan domestik. Kekerasan domestik sebetulnya tidak hanya menjangkau hubungan antara suami dengan istri dalam rumah tangga, namun termasuk juga kekerasan yang terjadi pada pihak lain yang berada dalam lingkup rumah tangga. Pihak lain tersebut adalah 1) suami, isteri, dan anak (termasuk anak angkat dan anak tiri); 2) orang-orang yang mempunyai hubungan keluarga dengan suami, istri dan anak karena hubungan darah, perkawinan, persusuan, pengasuhan, dan perwalian yang menetap dalam rumah tangga tersebut. 3) orang yang bekerja membantu rumah tangga dan menetap dalam rumah tangga tersebut. ${ }^{3}$ Dalam konvensi HAM Internasional "Universal Declaration of Human Rights ("UDHR"), the International Covenant on Civil and Political Rights ("ICCPR"), dan the International Covenant on Economic, Social and Cultural Rights ("ICESCR")telah diatur konsensus bersama yang menjadi standart umum mengenai Hak Asami Manusia, bahawa KDRT merupakan sebuah permasalahan dunia, yang mana setiap negara yang meratifikasinya harus memiliki komitmen kuat untuk pencegahan terhadap berbagai potensi

\footnotetext{
${ }^{1}$ Undang-Undang Nomor 23 Tahun 2004 tentang Penghapusan Kekerasan Dalam Rumah Tangga (UU PKDRT).

${ }^{2}$ Ibid

${ }^{3}$ Lingkup rumah tangga menurut Pasal 2 UU PKDRT Tahun 2004.
} 
tindak kekerasan dalam rumah tangga. Dalam hal ini para korban dari KDRT dapat menggugat negaranya masing-masing.

Berdasarkan hasil Catatan Tahunan (Catahu) ${ }^{4} 2016$ Komisi Nasional Anti Kekerasan Terhadap Perempuan (Komnas Perempuan) mengeluarkan catatan dan memberikan kesimpulan bahwa pada tahun 2015 kekerasan terhadap perempuan memperlihatkan pola yang meluas, sehingga penting agar negara hadir secara maksimal untuk terlibat dalam pencegahan, penanganan, serta tindakan strategis untuk menjamin rasa aman perempuan korban. Temuan Komnas Perempuan mencatat bahwa kekerasan terhadap perempuan tidak terjadi pada ranah dosmetik atau rumah tangga maupun dalam relasi perkawinan, tetapi terjadi meluas dimasyarakat umum maupun yang berdampak dari kebijakan negara. ${ }^{5}$ Dengan demikian bahwa kekerasan terhadap perempuan menjadi masalah serius yang harus direspon secara cepat dan tepat agar tidak terjadi permasalahan kompleks yang ditimbulkan dikemudian hari.

Catatan kekerasan personal (KDRT/Relasi Personal) Tahun 2016 sebanyak 321.752 kasus. Jenis kekerasan terhadap perempuan paling besar adalah kekerasan di ranah personal. Sementara bentuk kekerasan yang paling besar adalah kekerasan dalam bentuk fisik dan seksual. Hal ini berbeda dari tahun sebelumnya yang menemukan bentuk kekerasan yang terbesar adalah fisik dan psikis. Artinya terjadi kenaikan data kasus kekerasan seksual yang dilaporkan dibandingkan tahun sebelumnya. Adapun kekerasan dalam bentuk perkosaan sebanyak 72\% (2.399 kasus), dalam bentuk pencabulan sebanyak 18\% (601 kasus), dan pelecehan seksual 5\% (166 kasus). ${ }^{6}$ Data tersebut menunjukkan bahwa mayoritas

\footnotetext{
${ }^{4}$ Catatan Tahunan diluncurkan setiap tahun untuk memperingati hari hari Perempuan Internasional setiap

tanggal 8 Maret.

${ }^{5}$ Siaran Pers Komnas Perempuan Catatan Tahunan (Catahu) 2016 pada Tanggal 07 Maret 2016.

${ }^{6}$ lbid.
} 
korban-korban kekerasan dalam lingkup personal (domestik/ rumah tangga) adalah perempuan. Tidak dipungkiri bahwa perempuan tergolong menjadi kelompok rentan terhadap kekerasan, khususnya kekerasan dalam rumah tangga.

Selama ini kekerasan terjadi karena kurangnya komunikasi dan komitmen dalam satu keluarga untuk merespon dinamika/ permasalahan hidup, seringsekali perempuan dan anak yang justru menjadi korbannya. Dalam perspektif pekerjaan sosial, ini menjadi focus pekerja sosial untuk berperan dalam upaya menolong/ membantu pemulihan korban yang cenderung berdampak pada psikis yang tentunya menghambat hubungan relasi dan keberfungsian sosialnya, sehingga peran pekerja sosial dalam pendampingan sangat dibutuhkan sesuai amanat pasal 10 berkaitan HakHak Korban pada huruf (d) yakni pendampingan oleh pekerja sosial dan bantuan hukum pada setiap tingkat proses pemeriksaan sesuai dengan ketentuan peraturan perundang-undangan. ${ }^{7}$

Dalam penulisan ini akan dibahas lebih mendetail mengenai permasalahan Kekerasan Dalam Rumah Tangga (KDRT) terhadap perempuan mengenai bentuk-bentuk kekerasan, faktor, dampak dan penanganan dalam perspektif pekerjaan sosial. Dengan demikian diharapkan dapat memberikan sumbangsih bagi penanganan korban Kekerasan Dalam Rumah Tangga (KDRT) agar dapat diupayakan penanganan secara cepat dan tepat oleh pekerja sosial.

\section{B. Metode Penelitian}

Kajian penulisan ini menggunakan studi literatur. Menurut Burhan Bungin "Metode litaratur adalah salah satu metode pengumpulan data yang digunakan dalam metode penelitian sosial untuk menelusuri data

\footnotetext{
${ }^{7}$ UU No. 23 Tahun 2004 tentang PKDRT.
} 
histories". ${ }^{8}$ Artinya bahwa studi literatur merupakan sebuah studi yang menekankan pengumpulan data melalui penelusuran/ pengkajian bukubuku yang berkaitan dengan penelitian, dalam hal ini studi literatur difokuskan pada pengkajian buku-buku sosial yang relevan. Adapun metode analisis data yang digunakan adalah metode deskriptif analitis. Metode desriptif analitis adalah suatu usaha untuk mengumpulkan dan menyusun suatu data, kemudian diusahakan adanya analisis dan penafsiran data. ${ }^{9}$ Dengan kata lain metode deskriptif analitis memusatkan perhatian kepada permasalahan penelitian, sehingga hasil penelitian kemudian diolah dan dianalisis untuk diambil kesimpulannya.

\section{Bentuk-Bentuk KDRT}

Isu kekerasan perempuan dalam rumah tangga di Indonesia masih dipandang biasa, dan menganggap itu sebuah dinamika kehidupan yang harus dijalani. Sehingga banyak perempuan rumah tangga yang tidak berani untuk melaporkan kekerasan yang dialaminya karena beranggapan itu sebuah aib dalam keluarga yang tidak seharusnya orang lain mengetahuinya. Fenomena kekerasan tersebut seoalah seperti gunung es. Artinya bahwa kasus yang terungkap (publik) hanyalah sebagaian kecil dari bentuk kekerasan pada perempuan dalam rumah tangga yang belum terekspose kepermukaan. Tentu ini menjadi tugas semua pihak bahwa segala bentuk kekerasan harus dihilangkan, khususnya pada perempuan. Adapun bentuk-bentuk kekerasan dalam rumah tangga, yakni: ${ }^{10}$

1. Kekerasan Fisik, yakni perbuatan yang mengakibatkan rasa sakit, jatuh sakit, atau luka berat (Ps 5 jo 6). Kekerasan fisik dapat

\footnotetext{
${ }^{8}$ Burhan Bungin, Penelitian Kualitatif; Komunikasi, Ekonomi, Kebijakan Publik dan IImu Sosial Lainnya, (Jakarta: Kencana, 2008), hlm. 121.

${ }^{9}$ Winarno Surachmad, Pengantar Penelitian Ilmiah Dasar, (Bandung: Tarsito, 1985), hlm. 139.

${ }^{10}$ Bentuk-bentuk KDRT menurut Pasal 5 UU RI No. 23 Tahun 2004.
} 
dicontohkan seperti menendang, menampar, memukul, menabrak, mengigit dan lain sebagainya. Perbuatan yang mengakibatkan rasa sakit tersebut tentu harus mendapatkan penanganan medis sesuai kekerasan yang dialaminya.

2. Kekerasan Psikis, yakni perbuatan yang mengakibatkan ketakutan, hilangnya rasa percaya diri, hilangnya kemampuan untuk bertindak, rasa tidak berdaya, dan/ atau penderitaan psikis berat pada seseorang (Ps 5 jo 7). Dapat dicontohkan seperti perilaku mengancam, mengintimidasi, mencaci maki/ penghinaan, bullying dan lain sebagainya. Kekerasan psikis ini apabila terjadi pada anak tentu akan berdampak pada perkembangan dan psikis anak, sehingga cenderung mengalami trauma berkepanjangan. Hal ini juga dapat terjadi pada perempuan.

3. Kekerasan Seksual, yakni setiap perbuatan yang berupa pemaksaan hubungan seksual, pemaksaan hubungan seksual dengan cara tidak wajar dan/atau tidak disukai, pemaksaan hubungan seksual dengan orang lain untuk tujuan komersial dan/atau tujuan tertentu (Ps 5 jo 8), yang meliputi: (a) pemaksaan hubungan seksual yang dilakukan terhadap orang yang menetap dalam lingkup rumah tangga tersebut; (b) pemaksaan hubungan seksual terhadap salah seorang dalam lingkup rumah tangganya dengan orang lain untuk tujuan komersial dan/atau tujuan tertentu. Bentuk kekerasan seksual inilah yang biasa banyak terjadi pada perempuan, karena perempuan tergolong rentan.

4. Penelantaran Rumah Tangga, yakni perbuatan menelantarkan orang dalam lingkup rumah tangga, padahal menurut hukum yang berlaku bagi yang bersangkutan atau karena persetujuan atau perjanjian ia wajib memberikan kehidupan, perawatan, serta pemeliharaan 
kepada orang tersebut. Penelantaran juga berlaku bagi setiap orang yang mengakibatkan ketergantungan ekonomi dengan cara membatasi dan/atau melarang untuk bekerja yang layak di dalam atau di luar rumah sehingga korban berada di bawah kendali orang tersebut (Ps 5 jo 9). Dilihat dari penjelasan pasal tersebut, penelantaran rumah tangga tidak hanya disebut sebagai kekerasan ekomoni, namun juga sebagai kekerasan kompleks. Artinya bahwa bukan hanya penelantaran secara finansial (tidak memberi nafkah, tidak mencukupi kebutuhan, dII) melainkan penelantaran yang sifatnya umum yang menyangkut hidup rumah tangga (pembatasan pelayanan kesehatan dan pendidikan, tidak memberikan kasih sayang, kontrol yang berlebihan, dll).

\section{Faktor Penyebab KDRT}

Sedikitnya ada dua faktor penyebab kekerasan KDRT adalah Pertama, faktor internal akibat melemahnya kemampuan adaptasi setiap anggota keluarga diantara sesamanya, sehingga cenderung bertindak diskriminatif dan eksploitatif terhadap anggota keluarga yang lemah. Kedua, faktor eksternal akibat dari intervensi lingkungan di luar keluarga yang secara langsung atau tidak langsung mempengaruhi sikap anggota keluarga, yang terwujud dalam sikap eksploitatif terhadap anggota keluarga lain, khususnya terjadi terhadap perempuan dan anak. ${ }^{11}$

Selain itu Rocmat Wahab menyimpulkan bahwa KDRT ternyata bukan sekedar masalah ketimpangan gender. Hal tersebut acapkali terjadi karena kurangnya komunikasi, ketidakharmonisan, alasan ekonomi, ketidakmampuan mengendalikan emosi, ketidakmampuan mencari solusi masalah rumah tangga apapun, serta kondisi mabuk karena minuman

\footnotetext{
${ }^{11}$ Rochmat Wahab, Kekerasan Dalam Rumah Tangga: Perspektif Psikologis dan Edukatif. la adalah Pembantu

Rektor Bidang Akademik Universitas Negeri Yogyakarta (UNY) Tahun 2006- 2010.
} 
keras dan narkoba. ${ }^{12}$ Dalam banyak kasus terkadang pula suami melakukan kekerasan terhadap isterinya karena merasa frustasi tidak bisa melakukan sesuatu yang semestinya menjadi tanggung jawabnya.Halini biasanya terjadi pada pasangan yang belum siap kawin (nikah muda), suami belum memiliki pekerjaan dan penghasilan tetap untuk mencukupi kebutuhan, dan keterbatasan kebebasan karena masih menumpang pada orangtua/ mertua. Dari kondisi tersebut, sering sekali suami/ laki-laki mencari pelarian dengan hal-hal negatif (mabuk, judi, narkoba, seks) sehingga berujung pada pelampiasan terhadap isteri dengan berbagai bentuk, baik kekerasan fisik, psikis, seksual bahkan penelantaran.

Secara ringkas dapat dijelaskan bahwa penyebab KDRT terhadap perempuan bisa terjadi banyak faktor. Faktor diatas bukanlah satu-satunya penyebab, melainkan salah satu pemicu KDRT terhadap perempuan yang selama terus meningkat. Namun demikian, terlepas dari apapun penyebabnya, bahwa segala bentuk kekerasan baik yang terjadi terhadap perempuan merupakan kejahatan berat kemanusiaan. Hal ini apabila dibiarkan dan berlangsung secara terus menerus dapat mengakibatkan berbagai permasalahan baru dikemudian hari.

\section{E. Toeri KDRT Terhadap Perempuan}

1. Definisi Perempuan

Perempuan dalam Kamus Umum Bahasa Indonesia adalah lawan laki-laki, wanita. ${ }^{13}$ Dalam istilah ilmu sosial, perempuan dikenal dengan nama feminisme. Feminisme merupakan bagian dari ilmu sosial yang secara naluriah sangat problematik, karena hal ini akan selalu berkontaminasi dengan politik dan idiologi. Feminisme sebagai suatu gerakan pada mulanya berangkat dari asumsi bahwa kaum perempuan

\footnotetext{
${ }^{12}$ Ibid.

13 Poerwadarminta, Kamus Umum Bahasa Indonesia, (Jakarta: Balai Pustaka, 2003).
} 
pada dasarnya tertindas dan dieksploitasi, serta usaha untuk mengakhiri penindasan dan eksploitasi tersebut. ${ }^{14}$ Namun apabila dikaitkan dengan fenomena perempuan, maka yang berkembang selama ini menganggap bahwa kaum perempuan cenderung dilihat sebagai "korban" dari berbagai proses sosial yang terjadi dalam masyarakat selama ini. ${ }^{15}$ Menurut para feminis, pembagian kerja berdasarkan jenis kelamin, bukan saja merugikan perempuan, tetapi juga sudah tidak relevan lagi untuk diterapkan dalam masyarakat modern, karena laki-laki dan perempuan mempunyai peluang dan potensi yang sama untuk mengakses ke berbagai bidang profesi. ${ }^{16}$ Memperjuangkan perbaikan posisi dan kondisi kaum perempuan tidak sama dengan perjuangan kaum perempuan melawan laki-laki. Karena persoalan penindasan perempuan bukan datang dari laki-laki, melainkan persoalan sistem dan struktur ketidakadilan masyarakat dan, salah satunya, ketidakadilan gender. Gerakan kaum perempuan adalah gerakan transformasi yaitu suatu proses gerakan untuk menciptakan hubungan antar sesama manusia yang secara fundamental baru, lebih baik dan lebih adil. ${ }^{17}$ Oleh karena itu perlu adanya keberpihakan terhadap kaum perempuan, agar posisi dan peran perempuan tidak dipandang sebelah mata, melainkan melihat perempuan memiliki status dan peran yang seimbang dengan laki-laki. Dengan demikian memperjuangakan hak-hak perempuan adalah

\footnotetext{
14 Mansour Fakih, Analisis Gender dan Transformasi Sosial, (Jakarta: Pustaka Pelajar, 1996), hlm. 154-164.

${ }^{15}$ Riant Nugroho, "Gender Dan Strategi Pengarus-utamaanya”, (Yogyakarta: Pustaka Pelajar, 2008), hlm. 40.

${ }^{16}$ Zubaedi, Wacana Pembangunan Alternatif: Ragam Perspektif Pengembangan dan Pemberdayaan Masyarakat, (Yogyakarta: Ar-Ruzz, 2007), hlm, 280.

${ }^{17}$ Ibid, hlm. 164-165.
} 
bagian dari agenda besar dalam rangka perubahan mewujudkan keadilan gender.

2. Teori Dasar Terjadinya Kekerasan

Zastrow \& Browker 1984 (dalam Wahab, 2010) menyatakan bahwa ada tiga teori utama yang mampu menjelaskan terjadinya kekerasan, yaitu teori biologis, teori frustasi-agresi, dan teori kontrol. ${ }^{18}$

Pertama, teori biologis menjelaskan bahwa manusia, seperti juga hewan, memiliki suatu instink agressif yang sudah dibawa sejak lahir. Sigmund Freud menteorikan bahwa manusia mempunyai suatu keinginan akan kematian yang mengarahkan manusia-manusia itu untuk menikmati 6 tindakan melukai dan membunuh orang lain dan dirinya sendiri. Robert Ardery yang menyarankan bahwa manusia memiliki instink untuk menaklukkan dan mengontrol wilayah, yang sering mengarahkan pada perilaku konflik antar pribadi yang penuh kekerasan. Maksut teori biologis ini bahwa manusia memiliki instink agressif sejak lahir, sehingga perilaku konflik dianggap wajar sebagai bentuk untuk mempertahankan diri dari berbagai tekanan. Perilaku ini dapat terwujud sebagai bentuk kekerasan akibat adanya berbagai tekanan yang berkepanjangan (permasalahan keluarga, ekonomi, dll).

Kedua, teori frustasi-agresi menyatakan bahwa kekerasan sebagai suatu cara untuk mengurangi ketegangan yang dihasilkan situasi frustasi. Teori ini berasal dari suatu pendapat yang masuk akal bahwa sesorang yang frustasi sering menjadi terlibat dalam tindakan agresif. Contoh kasus seseorang suami yang sudah bertahun-tahun menganggur dan tidak mempunyai penghasilan tetap untuk memenuhi kebutuhan keluarganya, maka kecenderungan besar suami tersebut melakukan kekerasan terhadap isteri dan anaknya akibat gejala frustasi

\footnotetext{
${ }^{18}$ Rochmat Wahab, Kekerasan Dalam Rumah Tangga: Perspektif Psikologis dan Edukatif.
} 
yang dialaminya (bahkan ada yang dibunuh). Meskipun semuanya tidak seperti itu, tetapi dari banyak kasus yang terjadi, efek frustasi dapat mempengaruhi sesorang untuk melakukan tindak kekerasan.

Ketiga, teori kontrol menjelaskan bahwa orang-orang yang tidak terpuaskan dalam berelasi dengan orang lain akan mudah untuk melakukan kekerasan. Dengan kata lain, orang yang memiliki relasi yang baik dengan orang lain cenderung lebih mampu mengontrol dan mengendalikan perilaku yang agresif. Travis Hirschi memberikan dukungan kepada teori ini. Disebutkan bahwa remaja laki-laki yang berperilaku agresif cenderung tidak mempunyai relasi yang baik dengan orang lain. Hal sama juga terjadi pada eks narapidana di Amerika yang ternyata juga terasingkan dengan teman-teman dan keluarganya.

\section{F. Dampak KDRT Terhadap Perempuan}

Kasus tindak kekerasan merupakan masalah serius. Akibat yang ditimbulkan juga berdampak luas. Misalnya cacat, trauma, stress, timbul konfik bahkan pembunuhan, serta bagi anak dapat menganggu proses tumbuh kembang. Menurut hemat penulis, bahwa dampak KDRT terhadap perempuan dapat dibedakan menjadi 2 yakni, dampak jangka pendek dan dampak jangka panjang. Pertama, dampak jangka pendek biasanya berdampak secara langsung seperti luka fisik, cacat, kehamilan, hilangnya pekerjaan, dan lain sebagainya. Kedua, dampak jangka panjang biasanya berdampak dikemudian hari bahkan berlangsung seumur hidup. Biasanya korban mengalami gangguan psikis (kejiwaan), hilangnya rasa percaya diri, mengurung diri, trauma dan muncul rasa takut hingga depresi. Dari dua hal dampak tersebut, hal yang dikhawatirkan adalah munculnya kekerasan lanjutan. Artinya bahwa korban yang tidak tertangani dengan baik 
dikhawatirkan menjadi pelaku kekerasan dikemudian hari sebagai bentuk pelampiasan trauma masa lalu.

Emi Sutrisminah dalam penelitiannya mengungkapkan, dampak KDRT juga berpengaruh terhadap kesehatan reproduksi. Perempuan terganggu kesehatan reproduksinya bila pada saat tidak hamil mengalami gangguan menstruasi dapat mengalami penurunan libido dan ketidakmampuan mendapatkan orgasme. Sedangkan pada saat hamil, dapat terjadi keguguran/ abortus, persalinan formatur dan bayi meninggal dalam rahim. Dampak lain yang juga mempengaruhi kesehatan organ reproduksi istri dalam rumahtangga diantaranya adalah perubahan pola fikir, emosi dan ekonomi keluarga. ${ }^{19}$

\section{G. Perspektif Pekerjaan Sosial}

1. Konsep Pekerjaan Sosial

Menurut Edi Suharto, pekerjaan sosial adalah "aktivitas profesional untuk menolong individu, kelompok, dan masyarakat dalam meningkatkan atau memperbaiki kapasistas mereka agar berfungsi sosial dan menciptakan kondisi-kondisi masyarakat yang kondusif untuk mencapai tujuan tersebut". ${ }^{20}$ Max Siporin dalam buku karya Dwi Heru Sukoco pekerjaan sosial adalah "suatu metode institusi sosial untuk membantu orang mencegah dan memecahkan masalah mereka serta untuk memperbaiki dan meningkatkan keberfungsian sosial mereka"21

\footnotetext{
${ }^{19}$ Emi Sutriminah, Staff Pengajar Prodi D3 Kebidanan FIK Unissula, “Dampak Kekerasan Pada Istri Dalam Rumah Tangga Terhadap Kesehatan Reproduksi" jurnal online dapat di unduh di http://jurnal.unissula.ac.id/index.php/majalahilmiahsultanagung/article/view/62

${ }^{20}$ Edi Suharto, Pekerjaan Sosial di Dunia Industri: Memperkuat Tanggung Jawab Sosial Perusahaan, (Bandung: Rafika Aditama, 2007), hlm. 1.

${ }^{21}$ Dwi Heru Sukoco, Profesi Pekerjaan Sosial dan Proses Pengelolaanya, (Jakarta: Badan Pelatihan dan Pengembangan Sosial Depsos, 2005), hlm. 4.
} 
Definisi dua tokoh tersebut apabila dipahami bahwa pekerjaan sosial pada dasarnya menekankan sebuah aktivitas pertolongan profesional dengan menggunakan suatu metode dalam rangka meningkatkan dan membantu orang (individu, kelompok, masyarakat) memecahkan masalah mereka serta dapat meciptakan kondisi kondusif dan keberfungsian sosial mereka.

Adapun tujuan pekerjaan sosial menurut Asosiasi Nasional Pekerja Sosial di Amerika (National Association of Social Worker) sebagai berikut: ${ }^{22}$

a. Membantu individu-individu dan kelompok mengidentifikasi dan memecahkan masalah-masalah yang timbul dari ketidakseimbangan antara diri mereka sendiri dan lingkungan mereka.

b. Mengidentifikasi potensi aspek-aspek ketidakseimbangan antara individu-individu atau kelompok dan lingkungan dalam rangka mencegah terjadinya ketidakseimbangan.

c. Mengidentifikasi dan memperkuat potensi maksimal individu, kelompok, dan masyarakat.

Dengan mengambil kesimpulan diatas, bahwa pekerjaan sosial pada hakikatnya memiliki tujuan membantu baik individu, kelompok maupun masyarakat. Selain itu fokus utama tujuan pekerjaan sosial adalah meningkatkan keberfungsian sosial melalui motode intervensi yang tepat.

2. Pekerja Sosial: KDRT terhadap perempuan

Terkadang permasalahan sepele dapat mengakibatkan kekerasan terhadap perempuan. Itulah indikasi awal penyebab terjadinya tindak kekerasan dalam rumah tangga yang dialami perempuan. Berawal dari hal-

${ }^{22}$ Ibid. hlm. 20. 
hal sepele, terkadang dapat menimbulkan permasalahan yang serius. Namun selama ini permasalahan KDRT cenderung dianggap sebagai masalah pribadi dan aib keluarga, sehingga cenderung tertutup dan tidak berani untuk diungkapkan. Oleh karena itu, pekerja sosial harus mampu benar-benar meyakinkan korban perempuan untuk berani mengungkapkan permasalahan dan memberi rasa aman dan nyaman. Selain itu dalam menolong korban KDRT harus memiliki pengetahuan dan keberpihakan kepada korban bahwa kekerasan sekecil apapun, dengan bentuk apapun dan dilakukan oleh siapapun merupakan bentuk kejahatan kemanusiaan. Perspektif itulah yang nantinya menjadi dasar pertolongan bagi korban kekerasan KDRT yang marak terjadi di masyarakat.

Secara garis besar, penanganan KDRT dalam perspektif pekerjaan sosial dapat dilakukan dalam 2 tingkatan, yakni mikro (individu, keluarga, kelompok) dan makro (organisasi dan masyarakat). Keterkaitan kedua tingkatan tersebut merupakan sebuah level intervensi pekerjaan sosial yang paling utama, karena pada dasarnya pekerja sosial adalah jembatan dalam upaya penyelesaian masalah sosial, baik pada tingkat mikro, mezzo, maupun makro. Sehingga pekerja sosial dituntut untuk dapat menguasai metode dan strategi dalam upaya mewujudkan keberfungsian sosial di masyarakat.

Dalam penanganan korban KDRT terhadap perempuan, pekerja sosial sebagai profesi pertolongan harus terlibat dalam upaya penanganan terpadu dari berbagai sektor (kepolisian, komnas perempuan, kejaksaan, dII). Perspektif pekerjaan sosial, melihat bahwa korban KDRT harus segera mungkin untuk mendapatkan jaminan perlindungan dan keamanan serta pendampingan sosial agar korban dapat berfungsi sosial kembali. Berfungsi sosial kembali artinya bahwa korban diharapkan dapat melupakan kejadian yang tidak menyenangkan (melupakan trauma) dan dapat 
melakukan aktivitas sama halnya sebelum menjadi korban. Untuk mewujudkan itu, ada 2 hal pokok yang dapat dilakukan pekerja sosial, diantaranya pemberian konseling dan penyuluhan keluarga. Hal ini dilakukan dalam jangka pendek sebagai bentuk terapi agar korban tidak merasakan trauma berkepanjangan dan dapat berfikir dengan tenang.

Adapun kemampuan dasar pekerja sosial dalam upaya penanganan korban KDRT terhadap perempuan diantaranya:

1. Pekerja Sosial harus mampu melakukan assesment klien dengan berbagai metode pengumpulan data.

2. Mampu memahami kondisi klien dengan memperhatikan perkembangan psikologis dan kejiwaan klien.

3. Mampu mengidentifikasi sistem sumber dan kekuatan klien.

4. Mampu memprioritaskan kebutuhan klien dengan cepat, tepat dan akurat.

5. Mampu membuat rencana-rencana alternatif bagi klien.

6. Mampu melibatkan klien dalam pengambilan keputusan.

7. Mampu mendorong klien untuk berfikir positif dan menghilangkan trauma.

Dengan kemampuan tersebut, diharapkan upaya pemulihan dapat dilakukan secara maksimal baik secara medis maupun sosial. Oleh karena itu dibutuhkan peran pekerja sosial profesional dalam upaya penanganan korban KDRT terhadap perempuan. Karena upaya tersebut sudah di amanatkan dalam Pasal 22 UU No. 23 PKDRT Tahun 2004 yakni : (1). Dalam memberikan pelayanan, pekerja sosial harus : a. melakukan konseling untuk menguatkan dan memberikan rasa aman bagi korban; $b$. memberikan informasi mengenai hak-hak korban untuk mendapatkan perlindungan dari kepolisian dan penetapan perintah perlindungan dari pengadilan; c. mengantarkan korban ke rumah aman atau tempat tinggal 
alternatif; dan d. melakukan koordinasi yang terpadu dalam memberikan layanan kepada korban dengan pihak kepolisian, dinas sosial, lembaga sosial yang dibutuhkan korban. (2). Pelayanan pekerja sosial sebagaimana dimaksud pada ayat (1) dilakukan di rumah aman milik pemerintah, pemerintah daerah, atau masyarakat. Tujuan dari pasal tersebut jelas, bahwa pekerja sosial diwajibkan dalam upaya perlindungan dan pemulihan korban KDRT agar korban merasa aman dan tenang dalam menghadapi permasalahannya.

\section{H. Kesimpulan}

Kekerasan terutama kekerasan dalam rumah tangga merupakan pelanggaran hak asasi manusia dan kejahatan terhadap martabat kemanusiaan serta merupakan bentuk diskriminasi. Apabila dikaitkan dengan fenomena perempuan, maka yang berkembang selama ini menganggap bahwa kaum perempuan cenderung dilihat sebagai "korban" dari berbagai proses sosial yang terjadi dalam masyarakat selama ini. Oleh karena itu, sekecil apapun kekerasan yang dilakukan dapat dilaporkan sebagai tindak pidana yang dapat di proses hukum. Kekerasan dalam rumah tangga (KDRT) adalah setiap perbuatan terhadap seseorang terutama perempuan, yang berakibat timbulnya kesengsaraan atau penderitaan secara fisik, seksual, psikologis, dan/atau penelantaran rumah tangga termasuk ancaman untuk melakukan perbuatan, pemaksaan, atau perampasan kemerdekaan secara melawan hukum dalam lingkup rumah tangga.

Dalam penanganan korban KDRT terhadap perempuan, pekerja sosial harus terlibat dalam upaya penanganan terpadu dari berbagai sektor. Perspektif pekerjaan sosial memandang bahwa korban KDRT harus segera mungkin untuk mendapatkan jaminan perlindungan dan keamanan serta pendampingan sosial agar korban dapat berfungsi sosial kembali. 
E-ISSN: 2540-9182

P-ISSN: 2086-3357

Beberapa solusi untuk mencegah terjadinya tindak kekerasan dalam rumah tangga, mencegah KDRT antara lain :

1. Membangun kesadaran kepada masyarakat bahwa persoalan KDRT adalah persoalan sosial bukan individual dan merupakan pelanggaran hukum yang terkait dengan HAM.

2. Sosialiasasi kepada masyarakat bahwa KDRT adalah tindakan yang tidak dapat dibenarkan dan dapat diberikan sangsi hukum.

3. Mengkampanyekan penentangan terhadap penayangan kekerasan baik di media sosial, eletronik, maupun cetak.

4. Mendorong peranan media massa sebagai media untuk memberikan informasi mengenai pencegahan KDRT.

5. Mendampingi korban dalam penyelesaian persoalan serta menyediakan shelter (rumah aman) yang memiliki konselor terapis sebagai tempat pemulihan trauma.

\section{Daftar Pustaka}


Burhan Bungin, (2008). Penelitian Kualitatif; Komunikasi, Ekonomi, Kebijakan Publik dan IImu Sosial Lainnya, Jakarta: Kencana.

Dwi Heru Sukoco, (2007). Profesi Pekerjaan Sosial dan Proses Pengelolaanya, Jakarta: Badan Pelatihan dan Pengembangan Sosial Depsos.

Edi Suharto, (2007). Pekerjaan Sosial di Dunia Industri: Memperkuat Tanggungjawab Sosial Perusahaan, Bandung: Rafika Aditama.

Mansour Fakih, (1996). Analisis Gender dan Transformasi Sosial, Jakarta: Pustaka Pelajar.

Poerwadarminta, (2003). Kamus Umum Bahasa Indonesia, Jakarta: Balai Pustaka.

Riant Nugroho, (2008). “Gender Dan Strategi Pengarusutamaanya".Yogyakarta: Pustaka Pelajar.

Rochmat Wahab (2010), Jurnal Kekerasan Dalam Rumah Tangga: Perspektif Psikologis dan Edukatif.

Siaran Pers Komnas Perempuan Catatan Tahunan (Catahu) 2016 pada Tanggal 07 Maret 2016.

Undang-Undang Nomor 23 Tahun 2004 tentang Penghapusan Kekerasan Dalam Rumah Tangga (UU PKDRT).

Winarno Surachmad, (1985). Pengantar Penelitian Ilmiah Dasar, Bandung: Tarsito.

Zubaedi, (2007). Wacana Pembangunan Alternatif: Ragam Perspektif Pengembangan dan Pemberdayaan Masyarakat, Yogyakarta: Ar-Ruzz.

World Health Organization, World Report on Violence and Health 93 (2002), dapat diakses melalui www.who.int/violence injury prevention/violence/world report/en/

Emi Sutriminah, "Dampak Kekerasan Pada Istri Dalam Rumah Tangga Terhadap Kesehatan Reproduksi" jurnal online dapat di akses melalui 
E-ISSN: 2540-9182

P-ISSN: 2086-3357

http://jurnal.unissula.ac.id/index.php/majalahilmiahsultanagung/artic le/view/62 